\title{
Relevance of terpenoids on flammability of Mediterranean species: an experimental approach at a low radiant heat flux
}

\author{
Gianni Della Rocca ${ }^{(1)}$, \\ Javier Madrigal ${ }^{(2-3)}$, \\ Enrico Marchi ${ }^{(4)}$, \\ Marco Michelozzi ${ }^{(5)}$, \\ Bernabé Moya ${ }^{(6)}$, \\ Roberto Danti ${ }^{(1)}$
}

\begin{abstract}
One of the major factors influencing forest fuel combustion are terpenoids, a fraction of flammable Biogenic Volatile Organic Compounds (BVOCs) produced and stored by most Mediterranean species. The qualitative and quantitative effect of terpenoids on flammability has been only partially explained. In this study several major terpenoid-storing Mediterranean species (common cypress and three pines) were considered and compared to Holm oak as a reference non-storing species. The terpenoids were quantified via gas chromatography (GC-MS) analysis from both live fine fuel (LFF) and litter samples, and the relations between flammability and the terpenoids content were investigated by categories (Monoterpenoids, oxygenated Monoterpenoids, Sesquiterpenoids). The effect of fuel moisture content and species on ignition probability of LFF was also explored. A very different ignition probability was observed at the same fuel moisture content for the different species (Pinus spp. $>C$. sempervirens $>Q$. ilex). The stored terpenoids explained $19 \%$ to $50 \%$ of the whole flammability of both LFF and litter. Fuel moisture content (FMC) did not substantially change the relative effect of terpenoids on flammability, except in $C$. sempervirens. Monoterpenoids do not seem to significantly affect flammability, while sesquiterpenoids greatly influenced most flammability components, though their relative effect varied among species. A relation between storing structure of terpenoids and flammability was suggested. The results of this study indicate that isoprenoids should be included in physical models of the prediction and propagation of wildfire in Mediterranean vegetation as significant factors in driving flammability.
\end{abstract}

Keywords: Fuel Moisture Content, Ignition, Live Fine Fuel, Terpene-storing Species, Terpenoids Content, Sesquiterpenoids, Litter that enhance flammability could assist in forest management aimed at minimizing the consequences of wildfire (Ormeño et al. 2009, Ganteaume et al. 2013).

Forest fuel flammability depends upon several plant traits: (i) the physical properties (morphology, surface/volume ratio, crown architecture); (ii) the primary chemical traits (water content, percentage in li-
(1) Institute for Sustainable Plant Protection, IPSP-CNR. Via Madonna del Piano 10, I50019, Sesto Fiorentino, Firenze (Italy); (2) INIA -CIFOR, Department of Silviculture and Forest Management. Crta. A Coruña Km 7.5, 28040 Madrid (Spain); (3) iuFOR, Sustainable Forest Management Forest Institute UVa-INIA (Spain); (4) Dipartimento di Gestione dei Sistemi Agrari, Alimentari e Forestali - GESAAF, University of Florence, v. San Bonaventura 13, I50145, Firenze (Italy); (5) Institute of Biosciences and Bioresources, IBBR-CNR, Via Madonna del Piano 10, I-50019, Sesto Fiorentino, Firenze (Italy); (6) Avenida de Naquera 36, 46130, Valencia (Spain)

@ Roberto Danti (roberto.danti@ipsp.cnr.it)

Received: Dec 21, 2016 - Accepted: Jun 23, 2017

Citation: Della Rocca G, Madrigal J, Marchi E, Michelozzi M, Moya B, Danti R (2017). Relevance of terpenoids on flammability of Mediterranean species: an experimental approach at a low radiant heat flux. iForest 10: 766-775. - doi: 10.3832/ifor2327-010 [online 2017-09-02]

Communicated by: Davide Ascoli gnin, mineral/ash content); (iii) the presence/abundance of secondary flammable metabolites (Dimitrakopoulos \& Papaioannou 2001, Weise et al. 2005, Monti et al. 2008, Alessio et al. 2008a, 2008b, Cruz \& Alexander 2010, Pickett et al. 2010, Courty et al. 2012, Pausas et al. 2016); (iv) the vegetation structure (e.g., fuel loading, arrangement, packing ratio, porosity, dead:live ratio - Fernandes \& Cruz 2012). Many of these characteristics can also depends on the recurrence of fire and consequently to phenotypic adaptation of individual plant traits influencing flammability under different fire regimes (Pausas \& Moreira 2012, Moreira et al. 2014). All of those characteristics combined may determine different plant flammability, fire behaviour and fire regimes.

In addition to fuel moisture (Alessio et al. 2008b, Pickett et al. 2010), plant's volatile terpenoids have been considered as another possible important factor affecting flammability (Alessio et al. 2008b, Chetehouna et al. 2009, Ormeño et al. 2009, Courty et al. 2012, Ciccioli et al. 2014, Pausas et al. 2016). Most plant species of the Mediterranean vegetation are known to synthesize volatile terpenoids (hemiterpenoids, monoterpenoids and sesquiterpenoids) as secondary metabolites involved in 
the interaction of plants with their environment (Ormeño et al. 2007, Ciccioli et al. 2014, Karban et al. 2014). Some plant species exhibit specialized structures where the volatile compounds are stored (Loreto et al. 1996, Llusià\& Peñuelas 2000, Castro \& De Magistris 1999), while non-storing species produce and emit volatiles almost simultaneously (Loreto et al. 1996).

Terpenoids are the largest family of plant organic compounds including unsaturated (non-methane) hydrocarbons that result in an elevated flammability (Nuñez-Rigueira et al. 2005, Ciccioli et al. 2014) due to their high heating value and relatively low flash point. Differences in the terpenoid content among species, both in live fine fuel and litter, may have considerable implications for fire risk and could be important for fire management (Pausas et al. 2016, Varner et al. 2015). Terpenoids are not traditionally included as inputs in forest fire models and their influence in the behaviour of forest fires, including phenomena such as crown fires, is still uncertain. The most used fire modelling system (Andrews 2014), based on the Rothermel equation (Rothermel 1972) does not explicitly take into account the role of terpenoids to predict fire dynamics and the rate of spread at the head of a surface fire. Contrastingly, more complex physical models like FIRETEC (Linn et al. 2002) take into account gaseous-by products of forest fires, but no study has been carried out to assess the influence of terpenoids in fire behaviour using these multiphase models. More recently, the influence of terpenoids in accelerating forest fires has been evidenced at laboratory scale (Chetehouna et al. 2009) and modelled at larger scales (Chetehouna et al. 2014). Viegas \& Simeoni (2010) also hypothesize gas accumulation due to the production of volatile organic compounds as one of the possible causes of eruptive fires.

The high temperature reached in the proximity of fire front can determine the sudden emission of terpenoids by the vegetation and their physical diffusion, or they can be degassed afterwards when the termal degradation of specific storing structures (in storing species) is reached (Ciccioli et al. 2014).

White (1994) was among the first to hypothesize a relationship between monoterpenoids and the increase of forest fire frequency. Nuñez-Rigueira et al. (2005) assumed that the initiation and spread of forest fires is directly influenced by the essential oils/resins contained in the woody species, largely due to the accumulation of terpenoids. Liodakis et al. (2005) argued that the high flammability of Pinus halepensis could be linked to its storage of monoterpenoids. Owens et al. (1998) provided evidence of the positive relationship between leaf flammability and limonene (monoterpenoid) concentration. Pausas et al. (2016) recently confirmed that the capacity of Mediterranean plants to produce and store terpenoids can be considered as a flammability-enhancing trait. Barboni et al. (2011) and Raffalli et al. (2002) discussed the occurrence of "eruptive fires" and "fire flashover" in relation to the presence of dense terpenoids-storing species such as Pinus nigra and $P$. pinaster. On the other hand, the study of Alessio et al. (2008b) found the effect of terpenoid content on leaf flammability to be minimal or negligible. The role of volatile terpenoid content in live fuel flammability was investigated taking into consideration mainly their total amount (De Lillis et al. 2009) or the their most abundant fraction, the monoterpenoids, while less attention has been paid to the heavier volatile fraction of terpenoids (sesquiterpenoids - Owens et al. 1998, Alessio et al. 2008a, 2008b, Chetehouna et al. 2009).

Surface fuels, such as leaf litter and live fine fuel (leaves, scales, needles, fine shoots), may still contain terpenoids, as shown in conifers by Isidorov et al. (2003) and Ormeño et al. (2009). Even though the litter is quantitatively an important component of forest fuel and a crucial element for wildfire initial risk and propagation, few studies have focused on the link between the terpenoid content and flammability components of litter (Ormeño et al. 2009).

In summary, previous studies reported a positive (in many cases) relationship between the terpenoid content of forest fuel and its flammability, but the actual contribution of terpenoid content to vegetation flammability is still poorly quantified.

The objective of this study was to assess and quantify the role of the terpenoid content (monoterpenoids, oxygenated monoterpenoids and sesquiterpenoids fractions) in explaining the flammability (all its components sensu White \& Zipperer 2010) of fine live fuel and litter of major Mediterranean conifers, using a low radiant flux to better explore their effect on the different flammability phases.

\section{Materials and methods}

\section{Sampling and studied species}

In this study, we focused on four conifer species known to produce large amounts of terpenoids, which are mainly stored in foliar glands in Common cypress (Cupressus sempervirens) and in resin ducts in pine species (Pinus halepensis, P. pinaster, and $P$. pinea). Holm oak (Quercus ilex) instead was considered as a reference "zero-storing" species, as its terpenoids content is negligible compared to Mediterranean conifers (Alessio et al. 2008a). Therefore, values referring to Q. ilex were considered to be zero in all statistical analyses.

Fuel samples were collected in pure and mature pine plantations in Tuscany (central Italy) in September 2014, while fuel samples of common cypress (Cupressus sempervirens) were collected in adult plantations located in various Mediterranean countries (Italy, Portugal, Spain, France, Malta, Greece). A list of the sampling sites, including geographic and climatic data is reported in Tab. 1

In each sampling site, a bulk of $800 \mathrm{gr}$ samples of live fine fuel (LFF, twigs $\varnothing<0.6$ $\mathrm{cm}$ with foliage) were collected from the upper, middle and lower part of the crown from 8 healthy trees, using a telescopic saw. Dead fine fuel samples were collected from the litter of adult plantations in each site. Litter was sampled by collecting the bulk material included in 5 squares of $30 \times$ $30 \mathrm{~cm}$, up to the mineral soil. Stems, cones, branches and other organic or inorganic material were immediately removed from the collected samples.

To reduce the loss of water and terpenoids during transportation, the collected samples were quickly put into hermetic plastics zip-locked bags maintained at $5 \pm 2$ ${ }^{\circ} \mathrm{C}$ in portable refrigerators and transported to IPSP-CNR laboratory within a few hours. Cypress samples collected far from the lab were collected as described above and quickly sent to the laboratory by a $24 \mathrm{~h}$ courier in polystyrene box containing dry ice, with an ensured internal temperature of $5^{\circ} \mathrm{C}$.

\section{Effect of FMC and species on ignition probability (IP)}

A first trial was conducted on the LFF samples of C. sempervirens (CS), P. pinaster $(\mathrm{Ps}), \mathrm{P}$. halepensis (Ph), P. pinea (Pn), Q. ilex (Qi) to evaluate the effect of species and fuel moisture content (FMC) on the ignition probability (IP), which was defined as a binary variable (successful and unsuccessful ignition). Paired-samples were used for this experiment, one for the FMC determination and the other for the ignition test. A five-steps FMC gradient (measured on a $10 \mathrm{gr}$ of fuel sample) was obtained along an 8-day dehydration process at room conditions in the laboratory. Measurement of FMC (oven-drying the fuel at $100 \pm 2{ }^{\circ} \mathrm{C}$ ) and IP tests were performed the same day of sample collection and after 1 , 2,5 and 8 days. At the $8^{\text {th }}$ day, an additional series of ignition test was performed for each species on oven dried (to constant weight) fuel samples (sixth step, $F M C=0$ ). The IP was evaluated at a low radiant flux using an epiradiometer, simulating a lowmoderate fire condition (Cruz \& Alexander 2010), according to the methodology proposed by Della Rocca et al. (2015). A low radiant flux was adopted following Petriccione et al. (2006) to more effectively discriminate the flammability of components and to better explore differences among species. According to the procedure described by Valette (2007), Ganteaume et al. (2013), and Pausas et al. (2016), $1 \mathrm{~g}$ subsamples were picked up from the bulk of the sampled fuel (in such a way as to limit as much as possible their manipulation) and arranged on a metallic mesh positioned about $2.3 \mathrm{~cm}$ above the epiradiator so as to obtain a temperature of $250 \pm 5^{\circ} \mathrm{C}$ (approximately $25 \mathrm{~kW} \mathrm{~m}^{-2}$ ) measured in the centre of the mesh using a digital microprocessor 
thermometer with a platinum probe (Vittadini Delta OHM HD9214 ${ }^{\circledR}$, Padova, Italy). Using this approach, the contact between the fuel and the heater was avoided, and the energy was transferred as radiant heat, ensuring the flow of comburent during the test. For each of the 5 species, 10 ignition tests were replicated for each of 5 FMC gradient levels obtained during the dehydration process and for $F M C=0$ (for a total of 300 measures). The 0.5 IP $\left(M C_{50}\right)$ was calculated according to Santana \& Marrs (2014) to compare the effect due to FMC on the IP of the examined species.

\section{Relation between flammability and terpenoid content}

Before terpene analysis, three $100 \mathrm{~g}$ subsamples of each LFF sample collected at each site were used to determine the fuel moisture content (FMC) by oven-drying the material at $100 \pm 2^{\circ} \mathrm{C}$ for $24 \mathrm{~h}$ until a constant weight was reached. Three-four additional subsamples were immediately processed for terpenoids extraction (see below). The remaining LFF samples were stored in a refrigerated chamber $\left(4{ }^{\circ} \mathrm{C}\right)$ until they were tested for flammability, within three days since their collection.

The litter samples were stored in a conditioned chamber $\left(20{ }^{\circ} \mathrm{C}, 50 \% \mathrm{RH}\right)$ until FMC was stabilized at $10-12 \%$, determined as the difference between the weight of conditioned samples and that of the paired sample oven-dried at $100 \pm 2^{\circ} \mathrm{C}$ for $24 \mathrm{~h}$. Samples were then processed for terpenoid extraction and assayed for flammability.

Flammability tests were carried out on live fuel and litter samples of the 5 species (Tab. 1, Tab. 2), using an epiradiometer set as described in the previous experiment to simulate a low fire condition (Della Rocca et al. 2015). Forty $1 \mathrm{~g}$ subsamples were tested from each collection site, totalling 560 assays on LFF and 440 assays on litter
Tab. 1 - List of the fuel collection sites, with their main geographic and climatic features. (Elev): Elevation ( $m$ a.s.I.); $\left(T_{m}\right)$ : mean annual temperature; (Prec): mean annual precipitation.

\begin{tabular}{|c|c|c|c|c|c|}
\hline Species & $\begin{array}{l}\text { Provenance } \\
\text { (no, locality, region, country) }\end{array}$ & Lat/Long & $\begin{array}{l}\text { Elev } \\
(\mathrm{m})\end{array}$ & $\begin{array}{c}\mathrm{T}_{\mathrm{m}} \\
\left({ }^{\circ} \mathrm{C}\right)\end{array}$ & $\begin{array}{l}\text { Prec } \\
(\mathrm{mm})\end{array}$ \\
\hline \multirow{9}{*}{$\begin{array}{l}\text { Cupressus } \\
\text { sempervirens } \\
\text { (Cs) }\end{array}$} & (1) Aleria, Corse, France & $\begin{array}{r}42^{\circ} 05^{\prime} 3^{\prime \prime} \mathrm{N} \\
9^{\circ} 30^{\prime} 0^{\prime \prime} \mathrm{E}\end{array}$ & 42 & 15.5 & 734 \\
\hline & (2) Chania, Crete, Greece & $\begin{array}{l}35^{\circ} 22^{\prime} 0^{\prime \prime} \mathrm{N} \\
23^{\circ} 54^{\prime} 3^{\prime \prime} \mathrm{E}\end{array}$ & 684 & 19.7 & 816 \\
\hline & (3) Mgarr, Malta & $\begin{array}{l}37^{\circ} 50^{\prime} 0^{\prime \prime} \mathrm{N} \\
14^{\circ} 21^{\prime} 0^{\prime \prime} \mathrm{E}\end{array}$ & 27 & 18.8 & 553 \\
\hline & (4) São Brás, Algarve, Portugal & $\begin{array}{l}37^{\circ} 14^{\prime} 4^{\prime \prime} \mathrm{N} \\
7^{\circ} 56^{\prime} 5^{\prime \prime} \mathrm{W}\end{array}$ & 483 & 14.1 & 533 \\
\hline & (5) Troina, Sicily, Italy & $\begin{array}{l}37^{\circ} 50^{\prime} 1^{\prime \prime} \mathrm{N} \\
14^{\circ} 34^{\prime} 2^{\prime \prime} \mathrm{E}\end{array}$ & 994 & 12.3 & 545 \\
\hline & (6) Florence, Tuscany, Italy & $\begin{array}{l}43^{\circ} 49^{\prime} 3^{\prime \prime} \mathrm{N} \\
11^{\circ} 15^{\prime} 0^{\prime \prime} \mathrm{E}\end{array}$ & 248 & 14.5 & 864 \\
\hline & (7) Andilla 1, Valencia, Spain & $\begin{array}{r}39^{\circ} 50^{\prime} 5^{\prime \prime} \mathrm{N} \\
0^{\circ} 40^{\prime} 0^{\prime \prime} \mathrm{W}\end{array}$ & 923 & 14.5 & 446 \\
\hline & (8) Andilla 2, Valencia, Spain & $\begin{array}{r}39^{\circ} 50^{\prime} 5^{\prime \prime} \mathrm{N} \\
0^{\circ} 40^{\prime} 0^{\prime \prime} \mathrm{W}\end{array}$ & 923 & 14.5 & 446 \\
\hline & (9) Andilla 3, Valencia, Spain & $\begin{array}{l}39^{\circ} 50^{\prime} 5^{\prime \prime} \mathrm{N} \\
0^{\circ} 40^{\prime} 0^{\prime \prime} \mathrm{W}\end{array}$ & 923 & 14.5 & 446 \\
\hline $\begin{array}{l}\text { Pinus } \\
\text { halepensis (Ph) }\end{array}$ & $\begin{array}{l}\text { (10) Civitella M.ma, Tuscany, } \\
\text { Italy }\end{array}$ & $\begin{array}{l}42^{\circ} 59^{\prime} 3^{\prime \prime} \mathrm{N} \\
11^{\circ} 17^{\prime} 3^{\prime \prime} \mathrm{E}\end{array}$ & 266 & 13.8 & 873 \\
\hline $\begin{array}{l}\text { Pinus } \\
\text { pinaster }\end{array}$ & (11) Viareggio, Tuscany, Italy & $\begin{array}{l}43^{\circ} 48^{\prime} 6^{\prime \prime} \mathrm{N} \\
10^{\circ} 16^{\prime} 3^{\prime \prime} \mathrm{E}\end{array}$ & 7 & 14.6 & 925 \\
\hline (Ps) & (12) Monticiano, Tuscany, Italy & $\begin{array}{l}43^{\circ} 08^{\prime} 3^{\prime \prime} \mathrm{N} \\
11^{\circ} 12^{\prime} 3^{\prime \prime} \mathrm{E}\end{array}$ & 317 & 13.6 & 720 \\
\hline $\begin{array}{l}\text { Pinus pinea } \\
\text { (Pn) }\end{array}$ & (13) Cecina, Tuscany, Italy & $\begin{array}{l}43^{\circ} 17^{\prime} 3^{\prime \prime} \mathrm{N} \\
10^{\circ} 30^{\prime} 2^{\prime \prime} \mathrm{E}\end{array}$ & 18 & 14.1 & 873 \\
\hline $\begin{array}{l}\text { Quercus ilex } \\
\text { (Qi) }\end{array}$ & (14) Roselle, Tuscany, Italy & $\begin{array}{l}42^{\circ} 49^{\prime} 5^{\prime \prime} \mathrm{N} \\
11^{\circ} 09^{\prime} 5^{\prime \prime} \mathrm{E}\end{array}$ & 128 & 14.8 & 650 \\
\hline
\end{tabular}

samples. To thoroughly characterize flammability sensu White \& Zipperer (2010) the following parameters were measured: Ignition Frequency (IF, \%) and Time-to-ignition (TTI, s) for ignitability; Flame Height (FH, $\mathrm{cm}$ ) for combustibility; Flame Duration (FD, Fraction (RMF, \%) for consumability. For For both LFF and litter, 2-3 g subsamples each collection site the mean value was cal- of the collected material were ground in

Tab. 2 - Qualitative profile of terpenoids contained in both live fine fuel and litter of the conifer species analysed in this study. The terpenoids were grouped as Monoterpenoids (MT), Oxygenated Monoterpenoids (MTox) and Sesquiterpenoids (ST) and listed according to molecular weight in ascending order. For any compound the flash point and the boiling point (in ${ }^{\circ} \mathrm{C}$ ) are also reported. "+": compound identified in all replications; (+): compounds identified in less than $10 \%$ of the samples. (Cs): Cupressus sempervirens; (Ph): Pinus halepensis; (Ps): Pinus pinaster; (Pn): Pinus pinea.

\begin{tabular}{|c|c|c|c|c|c|c|c|c|c|c|c|c|}
\hline \multirow{2}{*}{ Terpenoid } & \multirow{2}{*}{$\begin{array}{l}\text { Terpenoid } \\
\text { class }\end{array}$} & \multirow{2}{*}{$\begin{array}{c}\text { Molecular } \\
\text { weight }\end{array}$} & \multirow{2}{*}{$\begin{array}{l}\text { Flash } \\
\text { point }\end{array}$} & \multirow{2}{*}{$\begin{array}{l}\text { Boiling } \\
\text { point }\end{array}$} & \multicolumn{3}{|c|}{ Live fine fuel (LLF) } & \multicolumn{3}{|c|}{ Litter } & \multirow[b]{2}{*}{ Ps } & \multirow[b]{2}{*}{$\mathrm{Pn}$} \\
\hline & & & & & Cs & $\mathrm{Ph}$ & Ps & Pn & Cs & $\mathrm{Ph}$ & & \\
\hline a-pinene & MT & 136.25 & 32.5 & 156 & + & + & + & + & + & + & + & + \\
\hline sabinene & MT & 136.25 & 36 & 164 & + & - & - & - & + & - & - & - \\
\hline b-pinene & MT & 136.25 & 36 & 166 & + & + & + & + & + & - & + & - \\
\hline d-3-carene & MT & 136.25 & 46 & 168.5 & + & + & + & - & + & + & + & + \\
\hline limonene & MT & 136.25 & 46.5 & 176 & + & + & + & + & + & + & - & + \\
\hline p-cymene & MT & 136.25 & 47 & 177 & + & + & + & + & $(+)$ & - & - & + \\
\hline g-terpinene & MT & 136.25 & 51 & 183 & + & + & - & - & + & + & - & - \\
\hline terpinolene & MT & 136.25 & 70 & 185 & + & + & + & - & + & - & + & - \\
\hline a-terpineol & Mtox & 154.25 & 90 & 219 & - & - & - & - & + & + & + & + \\
\hline citronellol & Mtox & 156.27 & 98 & 225 & - & - & - & - & $(+)$ & + & - & - \\
\hline linalool & MTox & 154.25 & 71 & 198 & $(+)$ & - & - & - & - & - & - & - \\
\hline 4ol-terpinen & MTox & 154.25 & 82 & 212 & + & - & - & - & - & - & - & - \\
\hline eugenol & Mtox & 164.21 & 120 & 254 & - & - & - & - & + & + & - & - \\
\hline geranylacetate & Mtox & 196.29 & 122 & 242 & - & - & - & - & + & - & - & + \\
\hline b-caryophyllene & ST & 204.35 & 96 & 263 & + & + & + & + & + & + & + & + \\
\hline
\end{tabular}


liquid nitrogen. Terpenes were extracted from $0.8 \mathrm{~g}$ of the obtained powder with 3.0 $\mathrm{mL}$ of $\mathrm{n}$-pentane with tridecane as an internal standard (Raffa \& Smalley 1995); the sample was filtered and $1 \mu \mathrm{L}$ volume was injected in the GC set to splitter mode (20:1 split ratio). Analyses were performed with a Gas Chromatograph Perkin-Elmer AutoSystem $\mathrm{XL}^{\oplus}$ equipped with an automatic sampler for liquid sample injections and with the TotalChrom ${ }^{\text {TM }}$ 6.2.0.0.0.:B27 chromatography software.

Gas chromatography analysis was carried out using hydrogen as carrier gas at $2.0 \mathrm{~mL}$ $\mathrm{min}^{-1}$ by a flame ionization detector at 250 ${ }^{\circ} \mathrm{C}$ and at injector temperature of $230{ }^{\circ} \mathrm{C}$. The oven temperature programming started at $40{ }^{\circ} \mathrm{C}$ for $3 \mathrm{~min}$ and increased to $200{ }^{\circ} \mathrm{C}$, at $1{ }^{\circ} \mathrm{C} \mathrm{min}^{-1}$; the final temperature of $200^{\circ} \mathrm{C}$ was maintained for $10 \mathrm{~min}$.

Terpenoids (mono- and sesquiterpenoids) were identified by comparison of retention times with those of standards under the same conditions. High-purity components were obtained from Fluka, Aldrich and Acros. The identified terpenoids were grouped according the molecular weight in 3 categories: monoterpenoids (MT), oxygenated monoterpenoids (MTox) and sesquiterpenoids (ST). For any identified compound the molecular weight, the flash point and the boiling point were derived from PubChem (http://pubchem.ncbi.nlm. nih.gov/). The amount of terpenoids was quantified in relation to the dry weight of samples.

\section{Selected variables and statistical analyses}

In the first experiment, the effect of FMC and species on IP was assessed using a logistic model (Hosmer \& Lemeshow 1980). The ignition success or unsuccess (yes/no) of fuel samples was selected as the dependent variable, while FMC (continuous) and species (categorical) were considered as independent variables.

In the second experiment, differences among species or provenances in the amount of BVOCs (Total BVOCs, TT, MT,
MTox, ST) detected in fine live fuel and in litter were compared by one-way ANOVA (Tukey's HSD test, $\mathrm{p}<0.05$ ). The proportion of terpenoids over the total BVOCs and the proportion of MT, MTox, ST over the total terpenoids were also compared among species/provenances. In the latter case angular transformation of data (Bliss 1938) was applied to comply with requirements of parametric analysis.

The influence of terpenoids on flammability was assessed using four independent variables, representing different terpenoids categories: total terpenoids (TT); monoterpenoids (MT), oxygenated monoterpenoids (MTox) and sesquiterpenoids (ST). The mean value of the measured terpenoids categories were used to generate the matrix of independent variables (predictors). Five dependent variables were selected to describe flammability (White \& Zipperer 2010): IF and TTI (ignitability), FH (combustibility), FD (sustainability) and RMF (consumability). As all litter samples ignited (IF 100\%), only TTI was used as ignitability predictor for litter samples.

The obtained matrix presented the same number of dependent and independent variables (4 dependent variables and 4 independent variables for litter and LFF samples), but a different number of data series ( $n=11$ for litter, $n=14$ for LFF) and a strong autocorrelation between TT and the other three categories selected as predictors (MT, MTox, ST). This type of data did not comply with parametric requirements and was therefore analyzed using nonparametric Partial Least Squares (PLS) models (Wold 1985). This method allowed the simultaneous fit of all dependent variables (flammability components) and detected the relative importance of independent variables (terpenoids).

The data was analyzed following a systematic/hierarchic process including: (i) all data series; (ii) C. sempervirens and Pinus data series; (iii) only C. sempervirens data series. The analysis was separately performed for litter and LFF samples, obtaining a total of six PLS linear models. Every

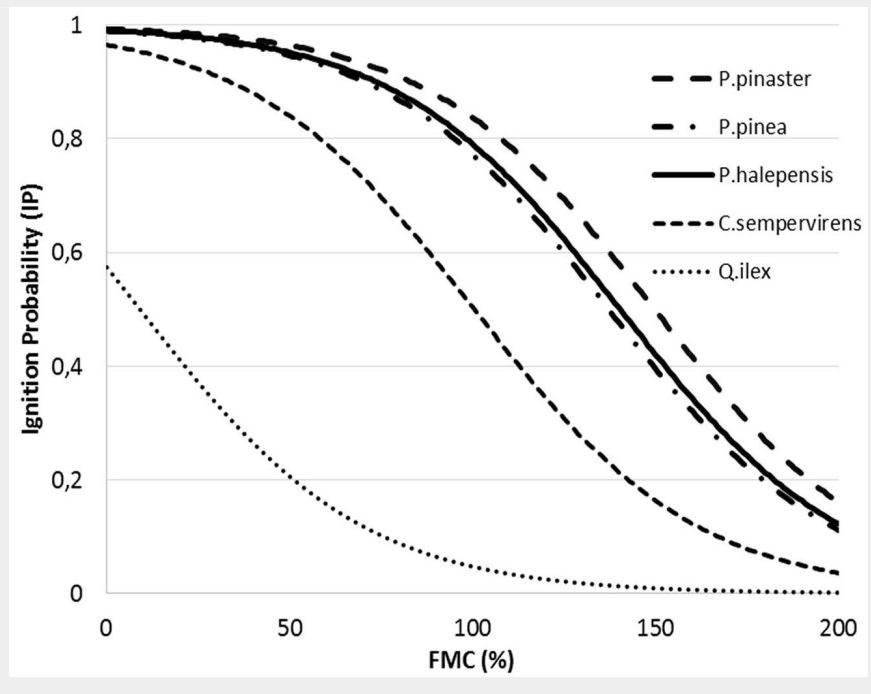

Fig. 1 - Logistic model IP=1/1+exp(logit) fitted using the first series of test to assess the effect of FMC (\%) and species on ignition probability $(\mathrm{n}=150)$ at $25 \mathrm{~kW}$ $\mathrm{m}^{-2}$. Logit $=3.30-$ 0.03 FMC-3.01 (Qi) $+1.62(P s)+1.31$ $(P h)+1.21(P n)+0$ moisture content (\% of dry weight). Species inputs are dummy variables (1/0). (CS). (FMC): Fuel model was simultaneously fitted using dependent (flammability) and independent (terpenoids) variables. All the models were also processed including FMC as independent variable, to avoid misinterpretation due to different FMC values among the samples. Therefore, the interpretation of the model was similar to a generalized linear model, guaranteeing its robustness. The scaled coefficient of the PLS models provided information about the positive or negative effect of each variable (sign) and relative weight in the fitted model (absolute value) as compared with the remaining independent variables. In this case, the coefficient sign reflects the positive or negative effect of the amount of terpenoids on flammability, whilst its absolute value indicates the relative importance in predicting each flammability variable.

PLS components were selected using the $\mathrm{Q}^{2}$ Stone-Geiser statistic. The number of selected components reflects the complexity of the data and the parameter $R^{2} X$ the cumulative percentage of autocorrelation. Model fitting was evaluated by the $R^{2} Y$ statistic, which is equivalent to the adjust$\mathrm{R}^{2}$ of parametric methods. The partial values of $R^{2} Y_{i}$ indicates the fit of each dependent variable $Y_{i}$ (flammability components).

The software package STATISTICA ${ }^{\oplus}$ ver. 10.0 (StatSoft, Tulsa, OK, USA) was used to conduct all statistical analyses.

\section{Results}

\section{Effect of FMC and species on IP}

The initial FMC of the LFF ranged from $76.7 \%$ in Q. ilex, $112.8 \%$ in P. pinaster, to $196.8 \%$ in C. sempervirens). Ignition probability (at $25 \mathrm{~kW} \mathrm{~m}^{-2}$ ) was predicted using a logistic model (Fig. 1). The original data used to perform this analysis are reported in Tab. S1 (Supplementary material). The model fit (Wald $\chi^{2}=60.02,-2 \mathrm{LL}_{F M C}=353.8$, $-2 L_{\text {species }}=208.6, p<0.01$, Area under ROC curve $c=0.87$ ) shows that FMC (as percent of dry weight) and species explain an important part of the IP (ignitability). Logistic curves clearly distinguish the pines from common cypress and holm oak. As FMC decreased under $200 \%$, differences of IP among the three genera of trees progressively increased, reaching a maximum around $120 \%$ FMC between C. sempervirens and Pinus spp., 75\% FMC between Q. ilex and Pinus spp., and 60\% FMC between Q. ilex and $C$. sempervirens; then differences in IP decreased. A 0.5 IP was reached at about $10 \%$ of FMC for holm oak, around $100 \%$ FMC for common cypress and from 135 to $150 \%$ FMC for pines. At FMC = o the IP of holm oak was about $60 \%$, while it was about $95 \%$ and $100 \%$ for cypress and pines, respectively.

\section{Flammability and terpenoid content}

The FMC of the LFF samples of the different conifer species ranged from $104.1 \%$ to $170.3 \%$ and for Q. ilex it was markedly lower 
Tab. 3 - Total BVOC content and profileof terpenoids ( $\mathrm{mg} \mathrm{g}^{-1}$ of dry weight, mean \pm standard deviation) for each species and provenance both for live fine fuel and litter, grouped by categories based on terpenoid molecular weight (MT: monoterpenoids; Mtox: oxygenated monoterpenoids; ST: sesquiterpenoids) and relative percentages. Different letters indicate significant differences between species/provenances for each BVOCs category in each column after Tukey's test $(p<0.05)$. Species labels and provenance numbers are the same as in Tab. 1. (nd): not detected.

\begin{tabular}{|c|c|c|c|c|c|c|c|c|c|c|c|}
\hline $\begin{array}{l}\text { Fuel } \\
\text { type }\end{array}$ & $\begin{array}{l}\text { Spe- } \\
\text { cies }\end{array}$ & Prov & $\begin{array}{l}\text { Total } \\
\text { BVoCs }\end{array}$ & $\begin{array}{l}\text { Total Terp. } \\
\text { (TT) }\end{array}$ & $\begin{array}{l}\text { MT } \\
\text { (not ox) }\end{array}$ & MTox & ST & $\begin{array}{l}\text { TT/Tot } \\
\text { BVOCs (\%) }\end{array}$ & $\begin{array}{l}\text { MT/TT } \\
(\%)\end{array}$ & $\begin{array}{l}\text { MTox/TT } \\
\text { (\%) }\end{array}$ & $\begin{array}{l}\mathrm{ST} / \mathrm{TT} \\
(\%)\end{array}$ \\
\hline \multirow{12}{*}{ 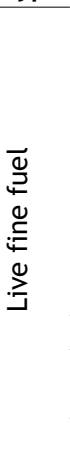 } & Cs & 1 & $1.42 \pm 0.07^{\text {ef }}$ & $1.10 \pm 0.06^{b c}$ & $1.06 \pm 0.06^{\mathrm{bc}}$ & $0.01 \pm 0.00^{\mathrm{a}}$ & $0.03 \pm 0.00^{\mathrm{ab}}$ & $77.54 \pm 0.49^{\text {cde }}$ & $96.40 \pm 0.11^{\text {ef }}$ & $0.70 \pm 0.06^{a}$ & $2.90 \pm 0.15^{\mathrm{g}}$ \\
\hline & & 2 & $3.70 \pm 0.36^{\mathrm{a}}$ & $2.80 \pm 0.29^{g}$ & $2.69 \pm 0.28^{\mathrm{h}}$ & $0.02 \pm 0.00^{\mathrm{b}}$ & $0.09 \pm 0.01^{d}$ & $75.55 \pm 0.94^{\mathrm{bcd}}$ & $95.95 \pm 0.23^{\mathrm{def}}$ & $0.80 \pm 0.03^{a}$ & $3.26 \pm 0.26^{\mathrm{g}}$ \\
\hline & & 3 & $2.03 \pm 0.10^{c d}$ & $1.60 \pm 0.07^{\mathrm{de}}$ & $1.54 \pm 0.07^{\mathrm{de}}$ & $0.03 \pm 0.00^{\mathrm{b}}$ & $0.03 \pm 0.00^{\mathrm{ab}}$ & $79.07 \pm 0.94^{\mathrm{de}}$ & $96.10 \pm 0.20^{\text {def }}$ & $1.76 \pm 0.08^{b}$ & $2.14 \pm 0.13^{\mathrm{fg}}$ \\
\hline & & 4 & $3.00 \pm 0.31^{b}$ & $2.21 \pm 0.25^{f}$ & $2.10 \pm 0.24^{\mathrm{g}}$ & $0.03 \pm 0.00^{\mathrm{b}}$ & $0.09 \pm 0.01^{d}$ & $73.45 \pm 1.13^{\mathrm{bc}}$ & $95.00 \pm 0.20^{c d}$ & $1.13 \pm 0.10^{c}$ & $3.87 \pm 0.25^{\mathrm{de}}$ \\
\hline & & 5 & $2.85 \pm 0.30^{\mathrm{b}}$ & $2.10 \pm 0.21^{f}$ & $2.00 \pm 0.20^{\mathrm{fg}}$ & $0.02 \pm 0.01^{\mathrm{b}}$ & $0.08 \pm 0.01^{c d}$ & $73.72 \pm 0.38^{\mathrm{bc}}$ & $95.39 \pm 0.17^{\text {cdef }}$ & $0.74 \pm 0.17^{\mathrm{a}}$ & $3.88 \pm 0.11^{\mathrm{de}}$ \\
\hline & & 6 & $2.50 \pm 0.29^{b c}$ & $2.15 \pm 0.29^{f}$ & $2.11 \pm 0.29^{g}$ & nd & $0.04 \pm 0.00^{\mathrm{abc}}$ & $86.60 \pm 1.29^{f g}$ & $97.95 \pm 0.19^{\mathrm{g}}$ & - & $2.05 \pm 0.19^{f g}$ \\
\hline & & 8 & $1.37 \pm 0.46^{\mathrm{ef}}$ & $1.01 \pm 0.31^{\mathrm{b}}$ & $0.96 \pm 0.30^{b}$ & nd & $0.05 \pm 0.01^{\mathrm{abcd}}$ & $74.19 \pm 2.20^{\mathrm{bcd}}$ & $95.31 \pm 0.24^{\text {cde }}$ & - & $4.69 \pm 0.24^{\mathrm{cd}}$ \\
\hline & & 9 & $1.77 \pm 0.18^{\mathrm{e}}$ & $1.45 \pm 0.28^{\text {cde }}$ & $1.44 \pm 0.28^{\mathrm{cde}}$ & nd & $0.02 \pm 0.00^{\mathrm{ab}}$ & $81.61 \pm 7.23^{\mathrm{ef}}$ & $98.64 \pm 0.30^{\mathrm{g}}$ & - & $1.36 \pm 0.30^{\mathrm{g}}$ \\
\hline & $\mathrm{Ph}$ & 10 & $3.57 \pm 0.20^{a}$ & $3.02 \pm 0.17^{g}$ & $1.67 \pm 0.14^{\mathrm{g}}$ & nd & $1.35 \pm 0.06^{e}$ & $84.56 \pm 0.51^{\mathrm{fg}}$ & $55.26 \pm 1.83^{\mathrm{a}}$ & - & $44.74 \pm 1.83^{a}$ \\
\hline & Ps & 11 & $2.56 \pm 0,20^{b}$ & $1.80 \pm 0.17^{\mathrm{ef}}$ & $1.64 \pm 0.15^{\mathrm{ef}}$ & nd & $0.16 \pm 0.02^{f}$ & $70.48 \pm 1.16^{\mathrm{ab}}$ & $91.10 \pm 0.45^{b}$ & - & $8.90 \pm 0.45^{b}$ \\
\hline & & 12 & $1.09 \pm 0.04^{f}$ & $0.96 \pm 0.03^{b}$ & $0.91 \pm 0.03^{b}$ & nd & $0.05 \pm 0.00^{\mathrm{bcd}}$ & $87.83 \pm 0.59^{9}$ & $94.34 \pm 0.15^{c}$ & - & $5.66 \pm 0.15^{c}$ \\
\hline & $\mathrm{Pn}$ & 13 & $0.18 \pm 0.01^{\mathrm{g}}$ & $0.18 \pm 0.01^{a}$ & $0.17 \pm 0.01^{a}$ & nd & $0.01 \pm 0.00^{\mathrm{a}}$ & $99.04 \pm 1.32^{h}$ & $94.99 \pm 0.27^{c d}$ & - & $5.01 \pm 0.27^{c d}$ \\
\hline \multirow{8}{*}{ 㐫 } & Cs & 2 & $6.71 \pm 1.72^{\mathrm{a}}$ & $3.52 \pm 0.88^{\mathrm{a}}$ & $3.37 \pm 0.85^{\mathrm{a}}$ & $0.05 \pm 0.02^{\mathrm{a}}$ & $0.11 \pm 0.02^{d}$ & $52.70 \pm 5.48^{\mathrm{abc}}$ & $95.46 \pm 1.20^{\mathrm{a}}$ & $1.31 \pm 0.42^{\mathrm{a}}$ & $3.23 \pm 0.80^{\mathrm{a}}$ \\
\hline & & 4 & $1.55 \pm 0.73^{b c}$ & $0.60 \pm 0.41^{c}$ & $0.53 \pm 0.38^{c}$ & $0.03 \pm 0.02^{\mathrm{a}}$ & $0.04 \pm 0.02^{d}$ & $36.06 \pm 10.42^{\mathrm{a}}$ & $86.92 \pm 4.36^{\mathrm{ab}}$ & $5.98 \pm 1.05^{\mathrm{a}}$ & $7.11 \pm 3.40^{\mathrm{a}}$ \\
\hline & & 7 & $2.22 \pm 1.32^{\mathrm{bc}}$ & $1.20 \pm 0.76^{\mathrm{bc}}$ & $1.16 \pm 0.72^{\mathrm{bc}}$ & $0.01 \pm 0.02^{\mathrm{a}}$ & $0.04 \pm 0.02^{\mathrm{cd}}$ & $53.14 \pm 5.38^{\mathrm{abc}}$ & $96.15 \pm 0.97^{\mathrm{a}}$ & $0.63 \pm 0.90^{\mathrm{a}}$ & $3.22 \pm 0.83^{\mathrm{a}}$ \\
\hline & & 8 & $1.87 \pm 0.29^{b c}$ & $1.02 \pm 0.36^{\mathrm{bc}}$ & $0.96 \pm 0.38^{\mathrm{bc}}$ & $0.01 \pm 0.01^{\mathrm{a}}$ & $0.05 \pm 0.03^{c d}$ & $53.65 \pm 13.13^{\mathrm{abc}}$ & $92.44 \pm 5.54^{\mathrm{ab}}$ & $1.52 \pm 1.29^{\mathrm{a}}$ & $6.04 \pm 4.32^{\mathrm{a}}$ \\
\hline & & 9 & $4.44 \pm 0.89^{\mathrm{ab}}$ & $2.52 \pm 0.52^{\mathrm{ab}}$ & $2.43 \pm 0.50^{\mathrm{ab}}$ & $0.05 \pm 0.01^{\mathrm{a}}$ & $0.05 \pm 0.01^{\mathrm{bc}}$ & $56.75 \pm 1.21^{\mathrm{abc}}$ & $96.26 \pm 0.20^{\mathrm{a}}$ & $1.81 \pm 0.19^{a}$ & $1.93 \pm 0.09^{\mathrm{a}}$ \\
\hline & $\mathrm{Ph}$ & 10 & $3.88 \pm 2.26^{\mathrm{ab}}$ & $2.44 \pm 1.42^{\mathrm{ab}}$ & $0.41 \pm 0.27^{c}$ & $0.09 \pm 0.03^{b}$ & $1.94 \pm 1.18^{a}$ & $63.06 \pm 0.45^{b c}$ & $16.02 \pm 2.41^{d}$ & $7.38 \pm 7.92^{\mathrm{a}}$ & $76.60 \pm 6.68^{c}$ \\
\hline & Ps & 11 & $0.68 \pm 0.75^{c}$ & $0.23 \pm 0.19^{c}$ & $0.08 \pm 0.04^{c}$ & $0.01 \pm 0.03^{\mathrm{a}}$ & $0.13 \pm 0.18^{a}$ & $54.12 \pm 33.53^{\mathrm{a}}$ & $50.69 \pm 25.31^{c}$ & $9.88 \pm 24.20^{a}$ & $39.43 \pm 31.46^{b}$ \\
\hline & $\mathrm{Pn}$ & 13 & $0.74 \pm 0.62^{\mathrm{c}}$ & $0.55 \pm 0.47^{c}$ & $0.46 \pm 0.41^{c}$ & $0.02 \pm 0.01^{\mathrm{a}}$ & $0.08 \pm 0.04^{\mathrm{a}}$ & $72.77 \pm 7.86^{c}$ & $75.84 \pm 12.10^{b}$ & $4.25 \pm 2.17^{\mathrm{a}}$ & $19.91 \pm 10.00^{\mathrm{ab}}$ \\
\hline
\end{tabular}

(77.1\%). As concerning the litter samples, FMC ranged from 10.9 to $12.9 \%$.

Analysis by GC-MS of the terpenoids contained in LFF of C. sempervirens, P. halepensis, $P$. pinaster and $P$. pinea led to the identification of 13 terpenoids: 10 monoterpenoids, one oxygenated monoterpenoids and two sesquiterpenoids; while litter of the same species contained 15 terpenoids: 9 monoterpenoids, 4 oxygenated monoterpenoids and two sesquiterpenoids. Tab. 2 reports the qualitative profile of the terpenoids identified in each species, both in LFF and litter.

For each species, the complete, quantitative profiles of the extracted compounds (both for LFF and litter), grouped in categories are listed in Tab. 3. The percentage of terpenoids on the total BVOCs, as well as the percentage of MT, MTox and ST on the total amount of terpenoids are also reported (Tab. 3). As concerning LFF, P. halepensis and some $C$. sempervirens provenances stored the highest amount of TT. Cupressus sempervirens was the species showing the highest accumulation of MT, though significant differences among provenances were observed, while $P$. halepensis and $P$. pinaster had the highest content of ST. Concerning the proportion of different categories of terpenoids, MT represented more than $90 \%$ of the total terpenes in all species or provenances, except in $P$. halepensis (55.3\%). Pines showed the highest content of ST (from $44.7 \%$ in $P$. halepensis to $5 \%$ in P. pinea - Tab. 3); C. sempervirens had the lower TT/Tot BVOCs ratio among all the examined spe- cies (mean 76.4\%), despite the considerable variability observed among provenances.

In the litter samples, the amount of TT was very low in $P$. pinaster and $P$. pinea ( 0.23 and $0.55 \mathrm{mg} \mathrm{g}^{-1}$ respectively) and slightly higher in P. halepensis and C. sempervirens (depending on the provenance in the latter species). The highest MT content was observed in $C$. sempervirens, while $P$. halepensis showed a significantly higher amount of ST (1.94 $\mathrm{mg} \mathrm{g}^{-1}$ - Tab. 3). The percentage of TT over the total BVOCs did not significantly differ among the examined species, except for $P$. pinea which showed a markedly higher value (72.8\%). The litter of pine species generally contained a lower percentage of MT and conversely a higher percentage of ST compared to $C$. sempervirens.

A qualitatively different isoprenoid profile among the species is clearly reported in Tab. 1, both for LFF and litter.

\section{Relationship between flammability and terpenoids}

Partial Least Squares models (Tab. 4) showed that terpenoid content accounts for $19 \%$ to $41 \%$ of the variation in flammability $\left(R^{2} Y\right.$ values), when FMC was not included as independent variable. When FMC was included in the models, the sum of terpenoids and FMC explained from $24 \%$ to $51 \%$ of the total variation. As expected, a strong autocorrelation was detected for the selected terpenoid variables $\left(R^{2} X\right.$ ranged from $39 \%$ to $90 \%$ without $F M C$, and from 37 to $93 \%$ including FMC), corroborating the use of the partial least square method to obtain robust results. Partial fits for dependent variables $\left(R^{2} Y_{i}\right.$ ranged from $1 \%$ to $63 \%$ without FMC, and from $1 \%$ to $65 \%$ with FMC) predicted some components of flammability more effectively than others and differences between litter and LFF data as well.

Litter flammability of all samples (model 1) presented a total fit of $32 \%$ but a higher fit for ignitability $\left(R^{2}{ }_{T T 1}=0.61\right)$, sustainability $\left(R_{F D}^{2}=0.29\right)$ and consumability $\left(R^{2}{ }_{R M F}=\right.$ $0.36)$ than the partial fit obtained for combustibility $\left(R_{F H}^{2}=0.01-\right.$ Tab. 4). When $Q$. ilex sample series (with negligible terpenoids contents) was removed (model 2), the total model and the partial fits were similar to model 1. The model obtained for cypress litter samples (model 3) showed that the flammability parameters were poorly correlated with the terpenoid content $\left(R^{2} Y=0.19-\right.$ Tab. 4).

When FMC was included as independent variable, the results did not substantially change. A decrease on the $R^{2} Y$ values concerning combustibility $\left(R^{2}{ }_{F H}=0.04\right)$ and sustainability $\left(R_{F D}^{2}=0.02\right)$ and an increase of consumability $\left(R_{R M F}^{2}=0.58\right)$ were observed only in model 3 (Tab. 4).

The total model fit resulted higher for LFF samples (models $4,5,6$ ) than for litter samples (models 1, 2, 3). Indeed, terpenoids explained between $35 \%$ and $50 \%$ of flammability for LFF and from 19\% to 36\% for litter (Tab. 4). Partial fits of flammability components in models 4 and 5 showed that the terpenoid content of samples explained combustibility and sustainability $\left(R_{F H}^{2}=52 \%\right.$; $\left.R_{F D}^{2}=63 \%\right)$ more effectively than ignitability 
Tab. 4 - PLS fits for the generated models. Model 1 and Model 4 were fitted using all data series (C. sempervirens+ Pinus spp. + Q. ilex); Model 2 and 5 were fitted after removal of Quercus ilex series (C. sempervirens+ Pinus spp.); Model 3 and 6 were fitted using only C. sempervirens series. Total model fit $\left(R^{2} Y\right.$ ), number of components (No. Comp, selected by $\mathrm{Q}^{2}$ Stone-Geiser statistic), autocorrelation of independent variables $\left(R^{2} X\right)$ and partial fits for flammability dependent variables $\left(R^{2} Y_{i}\right)$ are shown. All the models were also calculated including the FMC as independent variable (lower lines). (NIPALS): NonLinear Iterative PLS Algorithm; (a): litter; (b): live fine fuel.

\begin{tabular}{|c|c|c|c|c|c|c|c|c|c|}
\hline \multirow[b]{2}{*}{ State } & \multirow[b]{2}{*}{ Model } & \multicolumn{3}{|c|}{ Model fit (NIPALS) } & \multicolumn{4}{|c|}{ Partial fits $\left(R^{2} Y_{i}\right)$} & \multirow[b]{2}{*}{$\mathbf{R}_{\mathrm{RMF}}^{2}$} \\
\hline & & $\begin{array}{l}\text { No. } \\
\text { Comp }\end{array}$ & $Q^{2}$ & $\mathbf{R}^{2} \mathbf{X}$ & $\mathbf{R}^{2} \mathbf{Y}$ & $\begin{array}{l}\mathbf{R}_{\text {TTI }}{ }^{(\text {(a) }} \\
\mathbf{R}_{\text {IF }}^{2(b)}\end{array}$ & $\mathbf{R}_{\mathrm{FH}}^{2}$ & $\mathbf{R}_{\mathrm{FD}}^{2}$ & \\
\hline \multirow{6}{*}{ 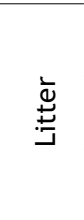 } & Model $1(n=11)$ & 1 & -0.08 & 0.42 & 0.32 & 0.61 & 0.01 & 0.29 & 0.36 \\
\hline & (including FMC) & 2 & -0.09 & 0.37 & 0.30 & 0.57 & 0.01 & 0.28 & 0.37 \\
\hline & Model $2(n=10)$ & 1 & -0.08 & 0.39 & 0.34 & 0.60 & 0.09 & 0.35 & 0.34 \\
\hline & (including FMC) & 2 & -0.08 & 0.81 & 0.36 & 0.55 & 0.12 & 0.40 & 0.37 \\
\hline & Model $3(n=7)$ & 2 & -0.72 & 0.94 & 0.19 & 0.39 & 0.14 & 0.24 & 0.34 \\
\hline & (including FMC) & 2 & -0.40 & 0.93 & 0.24 & 0.33 & 0.04 & 0.02 & 0.58 \\
\hline \multirow{6}{*}{ 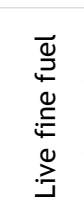 } & Model $4(n=14)$ & 2 & 0.11 & 0.90 & 0.40 & 0.34 & 0.63 & 0.53 & 0.08 \\
\hline & (including FMC) & 2 & 0.02 & 0.72 & 0.44 & 0.37 & 0.65 & 0.55 & 0.21 \\
\hline & Model $5(n=13)$ & 2 & 0.12 & 0.90 & 0.41 & 0.43 & 0.60 & 0.52 & 0.08 \\
\hline & (including FMC) & 2 & -0.02 & 0.63 & 0.49 & 0.52 & 0.62 & 0.53 & 0.27 \\
\hline & Model $6(n=9)$ & 2 & -0.06 & 0.88 & 0.35 & 0.39 & 0.44 & 0.32 & 0.24 \\
\hline & (including FMC) & 2 & -0.02 & 0.87 & 0.50 & 0.54 & 0.57 & 0.49 & 0.39 \\
\hline
\end{tabular}

$\left(R^{2}{ }_{\text {IF }}=34-43 \%\right)$ and consumability $\left(R^{2}{ }_{R M F}=\right.$ cially combustibility $\left(R_{F H}^{2}=44 \%\right)$. Including $8 \%$ ). In model 6 , all flammability variables FMC as independent variable, major differwere well explained by terpenoids, espe- ences were observed in models 4 and in model 5 concerning consumability $\left(\mathrm{R}^{2}{ }_{\mathrm{RMF}}\right.$ increased from $8 \%$ to $21 \%$ and from $8 \%$ to $27 \%$, respectively) and in model 6 (only common cypress), in which the variability explained by the sum of terpenoids and FMC increased for all the flammability components.

The influence of selected predictors on flammability for each model (scaled coefficient) is shown in Fig. 2 (terpenoids) and Fig. 3 (terpenoids and FMC). In Fig. 2, models 1, 2 and 3 refer to litter samples. Model 1 (litter samples using all data series, including Q. ilex, a non-storing terpenoids species) shows that MT and ST explain most of the variation in flammability (higher scaled coefficients - Fig. 2), that is, higher values of ST decrease TTI (higher ignitability) and RMF (consumability), and increase FD (sustainability); nevertheless higher values of MT decrease flammability of samples (higher TTI and RMF and lower FD). A similar trend was obtained for model 2 (excluding Q. ilex data series) which showed a greater and positive effect of ST on FD (combustibility). Model 3 (including only C. sempervirens series) showed that samples with high ST and MTox presented higher TTI, FH and lower FD, while the amount of MT and TT were related to higher FD and
Model 1, litter (pines+common cypress+holm oak

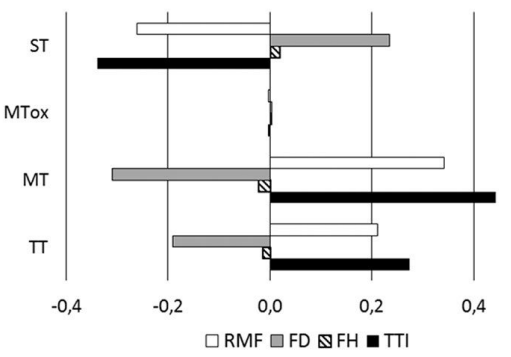

Model 2, litter (pines+common cypress)

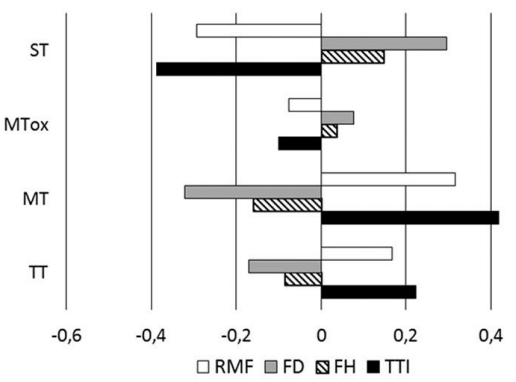

Model 3, litter (common cypress)

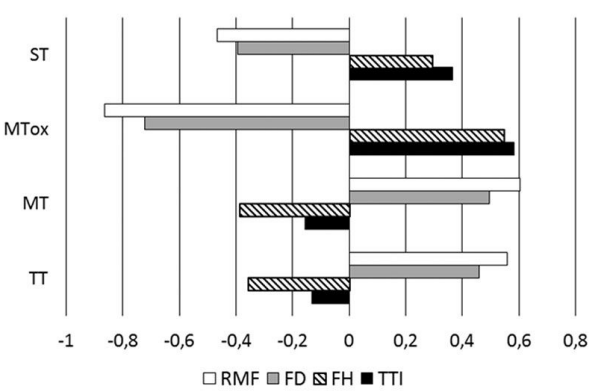

Model 4, leaves (pines+common cypresstholm oak)

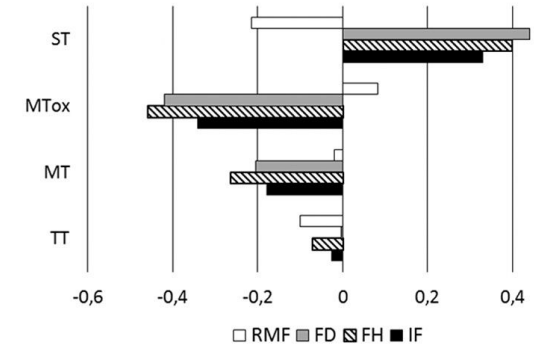

Model 5, leaves (pines+common cypress)

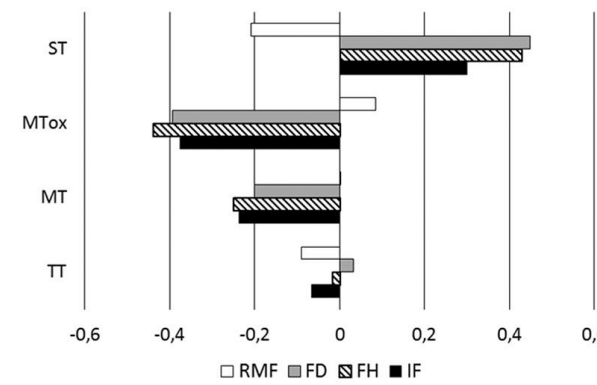

Model 6, leaves (common cypress)
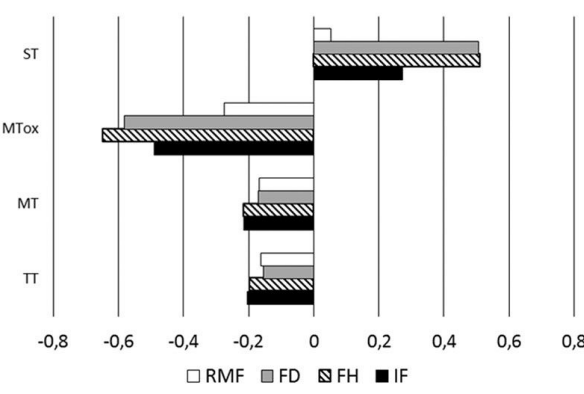

Fig. 2 - Scaled coefficients from PLS models (see Tab. 4 for details) excluding FMC as independent variable. Absolute values and sign of scaled coefficients for each terpenoid variable are shown. Predictors: (TT): total terpenoids; (MT): monoterpenoids; (MTox): oxygenated monoterpenoids; (ST): sesquiterpenoids. Dependent variables: (TTI): time-to-ignition; (IF): ignition frequency; $(\mathrm{FH})$ : flame height; (FD): flame duration; (RMF): residual mass fraction. 
Fig. 3 - Scaled coefficients from PLS models (see Tab. 4 for details)

including FMC as independent variable. Absolute values and sign of scaled coefficients for each terpenoid variable are shown. Predictors: (TT): total terpenoids; (MT): monoterpenoids; (MTox): oxygenated monoterpenoids; (ST): sesquiterpenoids. Dependent variables: (TTI): time-to-ignition; (IF): ignition frequency; (FH): flame height; (FD): flame duration; (RMF): residual mass fraction.
Model $1_{\mathrm{FMC}}$, litter (pines+common cypress+holm oak)

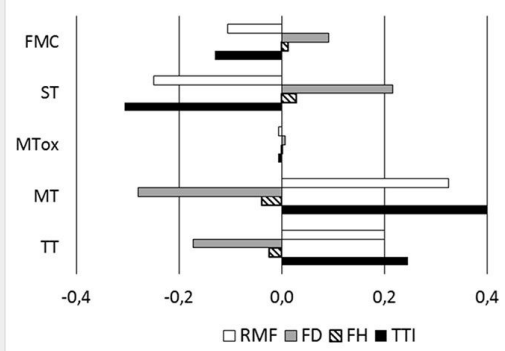

Model $2_{\mathrm{FMC}}$ litter (pines+common cypress)

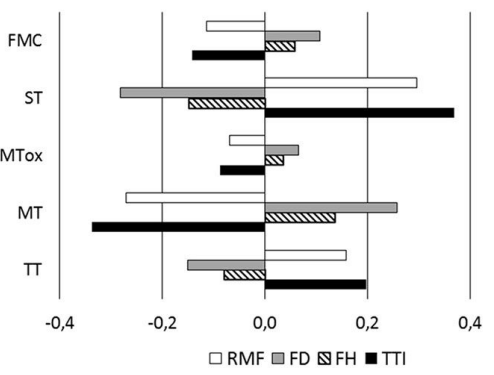

Model $3_{\mathrm{FMC}}$, litter (common cypress)

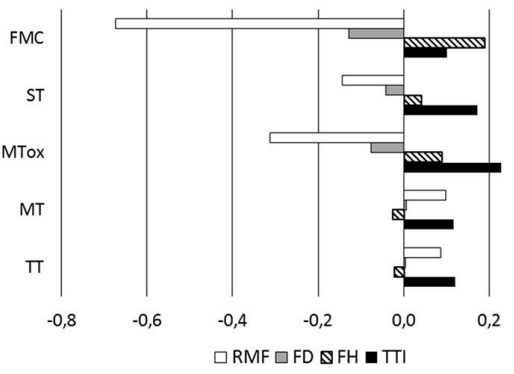

Model $4_{F M C}$ leaves (pines+common cypresstholm oak)

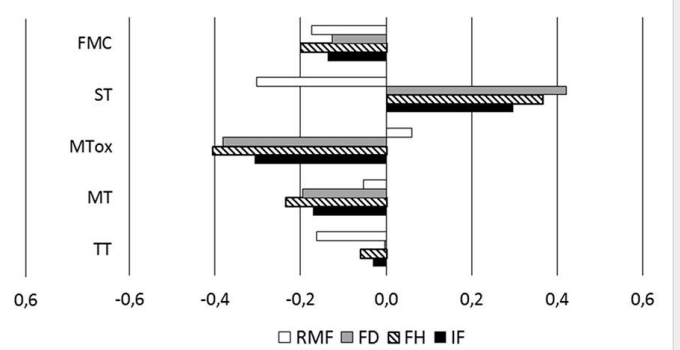

Model $5_{\mathrm{FMC}}$, leaves (pinestcommon cypress)

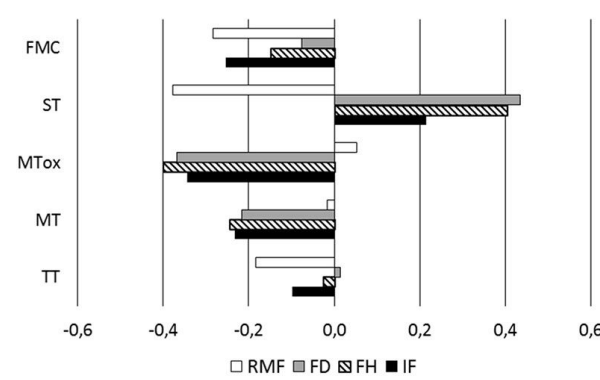

Model $\sigma_{F M C}$ leaves (common cypress)

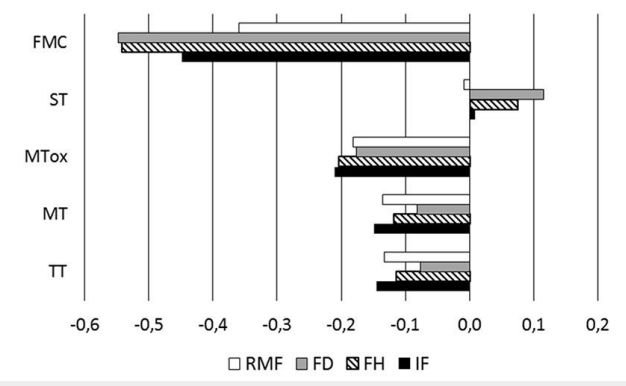

RMF; however, model 3 was characterized by a low partial fit $\left(R^{2} Y=19 \%\right.$ - Tab. 4$)$.

The relative importance of terpenoids was largely different for LFF samples (models 4, 5, and 6 - Fig. 2). The most important variable explaining the increase of flammability of live fuel samples was the ST, which was positively correlated with $\mathrm{FD}, \mathrm{FH}$ and IF, especially in model 4 and 5 (highest fits) which included the Pinus spp. samples and contained the highest amount of STs (particularly P. halepensis - Tab. 2). A high ST content strongly explained a longer FD, as well as a high FH and IF in all the three models. On the contrary, in the same three models (4, 5 and 6$)$ the same flammability parameters $\mathrm{FD}, \mathrm{FH}$ and IF were generally negatively correlated with the other categories of terpenoids especially the MTox (Fig. 2).

When FMC was included in the models as independent variable to assess the cumulative effect of both FMC and terpenoids (Fig. 3), model $1_{\mathrm{FMC}}$ was very similar to model 1 , while in model $2_{\text {FMC }}$ the effect of ST and MT on ignitability was inverted compared to model 2 , with TTI positively related to MT and negatively to ST. The greater difference was observed in model $3_{\text {FMC }}$ which indicate the relevant effect exerted by FMC on flammability (and in particular on consumability) of common cypress. In the same model, a positive relation was observed between FMC and FH and TTI (Fig. 3).

Regarding LFF, in model $4_{\mathrm{FMC}}$ (Fig. 3) most of the flammability was accounted for by $\mathrm{ST}$, which were positively related to FD, FH and IF, and by the MTox that resulted negatively related to the same flammability

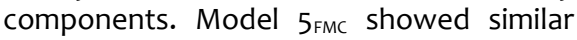
results to model 5 , while $F M C$ was negatively correlated to the all components of flammability in Model $\sigma_{\mathrm{FMC}}$ and resulted the more influencing factor (Fig. 3 ).

\section{Discussion}

Terpenoids represent a small fraction of the plant biomass (Llusià\& Peñuelas 2000). In this study the total amount of terpenoids ranged from $0.02 \%$ ( $P$. pinea) to $0.3 \%$ ( $P$. halepensis) in LFF, while in litter they varied from $0.03 \%$ ( $P$. pinaster) to $0.24 \%$ ( $P$. halepensis). This confirms that a fair amount of stored terpenoids lasts in the litter, as previously reported by Ormeño et al. (2009). Nevetheless, our results highlight that terpenoids significantly affect the flammability of surface fuel at low radiant flux both in the litter and in LFF (Tab. 4).

\section{Effect of FMC and species on IP}

The logistic model, created to evaluate the effect of FMC and species on IP, demonstrated that at low radiant flux and at a same FMC, pines showed a IP that was always much higher than that of holm oak and higher than that of common cypress. Despite the FMC is known as the main factor affecting IP in forest fuel (Van Wagner 1977, Gill et al. 1978, Chandler et al. 1983) at least in laboratory (Fernandes \& Cruz 2012), our logistic model demonstrates an important effect of the species on IP, at a same water content. This species-specific effect cannot be solely accounted for by physical traits, such as the surface area-to-volume ratio $(S / V)$. Indeed, based on the $S / V$ value (higher $S / V=$ higher flammability), the Mediterranean pines $\left(\mathrm{S} / \mathrm{V}=48-80 \mathrm{~cm}^{-1}\right.$ Valette 2007) should be more flammable than Q. ilex (40 $\mathrm{cm}^{-1}-$ Valette 2007), and C. sempervirens $\left(14 \mathrm{~cm}^{-1}\right.$ - Ganteaume et al. 2013) should be less flammable than Q. ilex (Pinus spp. $>$ Q. ilex $>$ C. sempervirens). Our results showed a higher IP in pines and a lower IP in Q. ilex (Pinus spp. > C. sempervirens $>$ Q. ilex). We can infer that the terpenoids could be at least partially responsible in altering the order based on the $S / \mathrm{V}$ value, i.e., the isoprenoid content of $C$. sempervirens might increase its IP compared to $Q$. ilex, which does not store terpenoids, despite its lower $S / \mathrm{V}$ ratio. This is confirmed by the fact that at $F M C=0$, the 
IP of Q. ilex reached a value around $60 \%$, while for cypress and pines it was $100 \%$. The low flammability of Q. ilex (that often pyrolyzes without igniting) could be due to the experimental setup (low heat flux and absence of the pilot flame) as well as to the absence of isoprenoids that hinder ignition. Other elements such as lignin, cellulose and mineral contents were not investigated in this study, though they could also play a role in determining the different IP values observed, as previously reported by Liodakis et al. (2002).

Our results also showed that common cypress leaves have to lose a much greater proportion of water content before ignition started, compared to the Mediterranean pines, confirming a relative ignition resilience (initial thermal inertia) of cypress LFF when samples are subjected to a relatively low heat flux $\left(25 \mathrm{~kW} \mathrm{~m}^{-2}\right.$ - Della Rocca et al. 2015).

\section{Relationship between flammability, terpenoids and FMC}

Fire behaviour is the result of dynamics and interactions of multiple effects, either synergistic or antagonistic, among which is the contribution of terpenoids on the four flammability components sensu White \& Zipperer (2010). Few previous studies focused on the identification of the major terpenoids molecules involved in flammability of vegetation (Owens et al. 1998, Ormeño et al. 2009, Pausas et al. 2016) and investigated the terpenoids-FMC interaction (Alessio et al. 2008a, De Lillis et al. 2009). During the early steps of this experiment, we tried to correlate the single terpenoids with the measured flammability parameters; we observed that similar molecules belonging to the same terpenoid category produced very different (if not contrasting) effects, without any apparent pattern. This had been already evidenced by Owens et al. (1998), who found opposite effects of similar terpenoids belonging to a same group (limonene and bornyl acetate) on flammability of Juniperus. The attempt to separate the effect of the single molecules may go over the real dynamic of a wildfire. Therefore, we focused on the effect on forest fuel flammability of groups of terpenoids sharing similar characteristics (molecular weight, flash point, boiling point).

Considering all the examined species, the greater effect of terpenoids on ignitability of litter compared to LFF (61\% and 34\% respectively) can be related to the lower FMC values and the lower variability of the FMC in litter (10-12\%) than in LFF (77.1$170.3 \%)$. Previous laboratory-scale studies identified LFF moisture content as a key flammability variable (Pausas et al. 2016), as water slows down the heat transmission to the fuel (plant tissues) and interacts with the terpenoids contained in the leaves (Alessio et al. 2008b, De Lillis et al. 2009). Nonetheless, our results indicated that FMC did not significantly affect the relative importance of terpenoids on sample flammability. When FMC was included in our models, the terpenoid effect was markedly reduced only on sustainability (FD) of $C$. sempervirens litter (model 3, from $24 \%$ to $2 \%$ ). Moreover, a minor participation of terpenoids to the combustion process in $\mathrm{Cu}$ pressus LFF was indicated by the lower $R^{2} Y$ fit value in Tab. 4 (model 6), confirming the empirical observation by Della Rocca et al. (2015). Further investigations should be addressed to study the role of water as carrier of some terpenoids, which may favour or slow down their escape during the preheating and the different stages of combustion, thus affecting their different contributions to flammability (Ciccioli et al. 2014).

In this study, the terpenoid content and quality differently affected the flammability components at low radiant flux. Total terpenoids and MT, that are the most significant fraction of terpenoids in LFF (9598.6\% both in C. sempervirens and Pinus spp., and $55 \%$ in P. halepensis), showed a slight negative effects on flammability (lower IF, lower FH and lower FD) in all the examined models. This is in agreement with the findings of Alessio et al. (2008a) for several Mediterranean shrubs and Owens et al. (1998) in Juniperus ashei for bornyl acetate. Contrastingly, the ST content was a reliable predictor of flammability for the LFF samples, in that higher values of ST increased ignitability (higher IF), sustainability (higher FD), combustibility (higher FH - Fig. 2, Fig. 3). Regarding the litter samples, the relationship between ST and flammability is less clear, in contrast to the findings by Ormeño et al. (2009) who observed higher ignition delay in species with higher $\gamma$-muurolene and $\delta$-cadinene (ST) compared to those with high MT content. The results of our trial conducted at a low heat flux suggest that the contribution of MT to flammability may be limited for the considered species, likely because of their high volatility which causes a rapid release before the ignition starts (Ciccioli et al. 2014). On the other hand, the highermolecular weight STs require a longer time to escape at low radiant flux, and could still be partially present in the leaf at the beginning of combustion, thus affecting the various flammability components. This effect could be hidden or minimized at higher heat flux (Kauf et al. 2014) and should be addressed by future studies. Moreover, further investigations are needed in species with different storing systems to elucidate the various mechanisms of terpenoids release at different radiant fluxes. Indeed, the lower loss of ST found in pines may be due to the deeper and more protected terpenoid storing site (resin ducts - BernardDegan 1988), which in cypresses are located in the subepidermal resin glands of leaves (Castro \& De Magistris 1999). In pines this could reduce the release of heavier sesquiterpenoids and non-volatile diterpenoids compounds, thus explaining the observed higher flammability of pine litter. In fact, resin is composed of roughly equal contents of volatile terpenoids ( $85 \%$ monoterpenoids and $15 \%$ sesquiterpenoids) and non-volatile diterpenoids (Steele et al. 1998).

The assessment of the impact of BVOCs on the ignition process can improve the characterization of the forest fuel dynamics and therefore can help to improve the risk indexes using other tools such as remote sensing (Fares et al. 2017). The bench-scale flammability experiments offer a limited insight on wildfire behaviour (Fernandes \& Cruz 2012). Nevertheless, some modelling approaches based on Froudescaling (Chetehouna et al. 2014) suggested that the results of flammability experiments and the implication of BVOCs could be potentially applied in field conditions. In this sense, physics-based models of flammability have the potential to deal with a continuous range of fuel properties and should allow to better understand the impact of fuel dynamics on wildfire spread (Fares et al. 2017). In general, physicallybased models performed better than the Rothermel model, suggesting that an improved understanding of the physical and chemical processes associated with ignition and propagation will improve our ability to predict fire spread (Weise et al. 2016). In addition, Finney et al. (2015) highlighted that wildfire spread depends on the interaction between flame dynamics induced by buoyancy and fine-particle response to convection, and suggested the existence of a missing components of wildfire spread. These evidences suggest that the knowledge of physical and chemical process can potentially contributes to improve physical-based model at real scale.

In the light of the results of this work, it seems increasingly advisable to includethe terpenoids in physical models for fire behavior prediction, at least as far as the Mediterranean vegetation is concerned (Osmont et al. 2015).

\section{Conclusions}

The relation between fuel moisture content (FMC) and the ignition probability (IP) varied across the studied species, with very different IP recorded at the same FMC value (Pinus spp. $>$ C. sempervirens $>$ Q. ilex). The terpenoid content in both live fine fuel (LFF) and litter explained from $19 \%$ to $41 \%$ of the total variation in flammability of the examined fuel samples at low radiant flux, and from $24 \%$ to $50 \%$ when FMC was included in the models. Monoterpenes (MT, about $90 \%$ of the volatile terpenoids) were negatively related to all the components of flammability in live fuel samples, whereas in litter samples they are negatively related to sustainability and ignitability. Sesquiterpenes (ST) affected all the components of flammability and were positively related to combustibility, sustainability and ignitability of fine live fuel, while in litter they affect negatively ignitability and consumability. 
The influence on flammability of both MT and ST was partially species-dependent and could be due to the different terpenoids storing mechanisms.

\section{Acknowledgments}

We would like to thank Gabriele Cencetti, technician at IBBR-CNR (Sesto Fiorentino, Italy) and Ms. Annalisa Pecchioli (fellowship holder) for their contribution in terpenoid extraction, David Caviglioli (student) for his work at the epiradiometer, and Dr. Matthew Haworth for the English grammar and styles revision.

This research was partially funded by COST Action FP1206 "European mixed forests - Integrating Scientific Knowledge in Sustainable Forest Management" (EuMIXFOR), and Programme Med "CYPFIRE" Project (2G-MED09-070, 2010-2013). INIA participation was partially supported by EraNet FORESTERRA, MedWildFireLab project (PCIN-2013-141-C04-04).

\section{Authors' contribution}

$G D R, R D$, and $J M$ designed the experiment. GDR, RD, EM, and BM performed the laboratory work. GDR, RD, and MM carried out the chemical analyses. JM, RD, and GDR did the statistical analyses. GDR wrote the manuscript and all authors contributed with corrections.

\section{References}

Alessio GA, Peñuelas J, De Lillis M, Llusià J (2008a). Implications of foliar terpene content and hydration on leaf flammability of Quercus ilex and Pinus halepensis. Plant Biology 10: 123128. - doi: 10.1111/j.1438-8677.2007.00011.x Alessio G, Peñuelas J, Lusia J, Ogaya R, Estiarte $M$, De Lillis M (2008b). Influence of water and terpenoids on flammability in some dominant Mediterranean species. International Journal of Wildland Fire 17: 274-286. - doi: 10.1071/WF070 38

Andrews PL (2014). Current status and future needs of the BehavePlus Fire Modeling System. International Journal of Wildland Fire 23: 21-33. - doi: 10.1071/WF12167

Barboni T, Cannac M, Leoni E, Chiaramonti N (2011). Emission of biogenic volatile organic compounds involved in eruptive fire: implications for the safety of firefighters. International Journal of Wildland Fire 20 (1): 152-161. - [online] URL: http://www.publish.csiro.au/wf/wfo8122

Bernard-Degan C (1988). Seasonal variations in energy sources and biosynthesis of terpenoids in maritime pine. In: "Mechanisms of Woody Plant Defenses Against Insects" (Mattson WJ, Levieux J, Bernard-Degan C eds). Springer, New York, USA, pp. 93-116.

Bliss $\mathrm{Cl}$ (1938). The transformation of percentages for use in the analysis of variance. Ohio Journal of Science 38: 9-12. [online] URL: http:// kb.osu.edu/dspace/bitstream/handle/1811/2917/ V38N01_009.pdf

Castro MA, De Magistris AA (1999). Ultrastructure of foliar secretory cavity in Cupressus arizonica var. glabra (Sudw.) Little (Cupressaceae). Biocell 23: 19-28.

Chandler C, Cheney P, Thomas P, Trabaud L,
Williams D (1983). Fire in forestry. Vol I. Forest fire behaviour and effects. John Wiley and Sons, New York, USA, pp. 450. [online] URL: http://www.cabdirect.org/cabdirect/abstract/19 850699124

Chetehouna K, Barboni T, Zarguili I, Leoni E, Simeoni A, Fernandez-Pello AC (2009). Investigation on the emission of volatile organic compounds from heated vegetation and their potential to cause an eruptive forest fire. Combustion Science Technology 181: 1273-1288. doi: $10.1080 / 00102200903181827$

Chetehouna K, Courty L, Garo JP, Viegas DX, Fernandez-Pello C (2014). Flammability limits of biogenic volatile organic compounds emitted by fire-heated vegetation (Rosmarinus officinalis) and their potential link with accelerating forest fires in canyons: a Froude-scaling approach. Journal of Fire Science 32: 459-479. doi: 10.1177/0734904113514810

Ciccioli P, Centritto M, Loreto F (2014). Biogenic volatile organic compound emissions from vegetation fires. Plant, Cell and Environment 37: 1810-1825. - doi: 10.1111/pce.12336

Courty L, Chetehouna K, Lemée L, MounaïmRousselle C, Halter F, Garo JP (2012). Pinus pinea emissions and combustion characteristics of limonene potentially involved in accelerating forest fire. International Journal of Thermal Sciences 57: 92-97. - doi: 10.1016/j.jjthermalsci.20 12.02.012

Cruz MG, Alexander ME (2010). Assessing crown fire potential in coniferous forests of western North America: a critique of current approaches and recent simulation studies. International Journal of Wildland Fire 19: 377-398. doi: 10.1071/WFo8132

De Lillis M, Bianco PM, Loreto F (2009). The influence of leaf water content and terpenoids on flammability of some Mediterranean woody species. International Journal of Wildland Fire 18: 203-212. - doi: 10.1071/WF07075

Della Rocca G, Hernando C, Madrigal J, Danti R, Moya J, Pecchioli A, Moya B, Guijarro M (2015). Possible land management uses of common cypress to reduce wildfire. Initiation risk: a laboratory study. Journal of Environmental Management 159: 68-77. - doi: 10.1016/j.jenvman.2015. 05.020

Dimitrakopoulos AP, Papaioannou KK (2001). Flammability assessment of Mediterranean forest fuels. Fire Technology 37: 143-152. - doi: 10.10 23/A:1011641601076

Fares S, Bajocco S, Salvati L, Camarretta N, Dupuy JL, Xanthopoulos G, Guijarro M, Madrigal J, Hernando C, Corona P (2017). Characterizing potential wildland fire fuel in live vegetation in the Mediterranean region. Annals of Forest Science 74: 1. - doi: 10.1007/s13595-016-0599-5 Fernandes PM, Cruz MG (2012). Plant flammability experiments offer limited insight into vegetation-fire dynamics interactions. New Phytologist 194: 606-609. - doi: 10.1111/j.1469-8137.2012. 04065.x

Fernandes PM, Barros AM, Pinto A, Santos JA (2016). Characteristics and controls of extremely large wildfires in the western Mediterranean Basin. Journal of Geophysical Research: Biogeosciences 121 (8): 2141-2157. - doi: 10.1002/ 2016JG003389

Finney MA, Cohen JD, Forthofer JM, McAllister
SS, Gollner MJ, Gorham DJ, Saito K, Akafuah NK, Brittany AA, English JD (2015). Role of buoyant flame dynamics in wildfire spread. Proceedings of the National Academy of Sciences USA 112: 9833-9838. - doi: 10.1073/pnas.150449 8112

Ganteaume A, Jappiot M, Lampin C, Guijarro M, Hernando C (2013). Flammability of some ornamental species in wildland-urban interfaces in South-eastern France: laboratory assessment at particle level. Environmental Management 52: 467-480. - doi: 10.1007/s00267-013-0067-z

Gill AM, Trollope WSW, MacArthur DA (1978). Role of moisture in the flammability of natural fuels in the laboratory. Australian Forest Research 8: 199-208.

Hosmer DW, Lemeshow S (1980). A goodnessof-fit test for the multiple logistic regression model. Communications in Statistics-Theory and Methods 9 (10): 1043-1069. - doi: 10.1080/03 610928008827941

Isidorov VA, Vinogorova VT, Rafalowski K (2003). HS-SPME analysis of volatile organic compounds of coniferous needle litter. Atmospheric Environment 37: 4645-4650. - doi: 10.101 6/j.atmosenv.2003.07.005

Karban R, Wetzel WC, Shiojiri K, Ishizaki S, Ramirez SR, Blande JD (2014). Deciphering the language of plant communication: volatile chemotypes of sagebrush. New Phytologist 204: 380-385. - doi: 10.1111/nph.12887

Kauf Z, Fangmeier A, Rosavec R, Španjol Z (2014). Testing vegetation flammability: the problem of extremely low ignition frequency and overall flammability score. Journal of Combustion: 1-10. - doi: 10.1155/2014/970218

Linn RR, Reisner J, Colman J, Winterkamp J (2002). Studying wildfire using FIRETEC. International Journal of Wildland Fire 11: 1-14. - doi: 10.1071/WF02007

Liodakis S, Bakirtzis D, Dimitrakopoulos A (2002). Ignition characteristics of forest species in relation to thermal analysis data. Thermochimica Acta 390 (1): 83-91. - doi: 10.1016/So0406031(02)00077-1

Liodakis S, Vorisis D, Agiovlasitis IP (2005). A method for measuring the relative particle fire hazard properties of forest species. Thermochimica Acta 437: 150-157. - doi: 10.1016/j.tca.20 05.07.001

Llusià J, Peñuelas J (2000). Seasonal patterns of terpenoid content and emission from seven Mediterranean woody species in field conditions. American Journal of Botany 87: 133-140. doi: $10.2307 / 2656691$

Loreto F, Ciccioli P, Brancaleoni E, Cecinato A, Frattoni M, Sharkey TD (1996). Different sources of reduced carbon contribute to form three classes of terpenoid emitted by Quercus ilex L. leaves. Proceedings of the National Academy of Sciences USA 93: 9966-9969. - doi: 10.1073/pnas.93.18.9966

Monti A, Di Virgilio N, Venturi G (2008). Mineral composition and ash content of six major energy crops. Biomass and Bioenergy 32: 216223. - doi: 10.1016/j.biombioe.2007.09.012

Moreira B, Castellanos MC, Pausas JG (2014). Genetic component of flammability variation in a Mediterranean shrub. Molecular Ecology 23: 1213-1223. - doi: 10.1111/mec.12665

Nuñez-Regueira L, Rodriguez-Anon JA, Proupin 
J, Mourino B, Artiaga-Diaz R (2005). Energetic study of residual forest biomass using calorimetry and thermal analysis. Journal of Thermal Analysis and Calorimetry 80 (2): 457-464. - doi: 10.1007/s10973-005-0677-7

Ormeño E, Fernandez C, Mévy JP (2007). Plant coexistence alters terpene emission and content of Mediterranean species. Phytochemistry 68: 840-852. - doi: 10.1016/j.phytochem.2006.11. 033

Ormeño E, Céspedes B, Sánchez IA, Velasco-García A, Moreno JM, Fernandez C, Baldy V (2009). The relationship between terpenoids and flammability of leaf litter. Forest Ecology and Management 257: 471-482. - doi: 10.1016/j.foreco.20 08.09.019

Osmont A, Chetehouna K, Chaumeix N, DeYonker NJ, Catoire L (2015). Thermodynamic data of known volatile organic compounds (VOCs) in Rosmarinus officinalis: implications for forest fire modelling. Computational and Theoretical Chemistry 1073: 27-33. - doi: 10.1016/ j.comptc.2015.09.008

Owens MK, Lin C-D, Taylor Jr CA, Whisenant S (1998). Seasonal patterns of plant flammability and monoterpenoid content in Juniperus ashei. Journal of Chemical Ecology 24: 2115-2129. - doi: 10.1023/A:1020793811615

Pausas JG, Alessio GA, Moreira B, Segarra-Moragues JG (2016). Secondary compounds enhance flammability in a Mediterranean plant. Oecologia 180 (1): 103-110. - doi: 10.1007/s00442015-3454-8

Pausas JG, Moreira B (2012). Flammability as a biological concept. New Phytologist 194: 610613. - doi: 10.1111/j.1469-8137.2012.04132.x

Petriccione M, Moro C, Rutigliano FA (2006). Preliminary studies on litter flammability in Mediterranean region. Forest Ecology and Management 234: S128-S128.

Pickett BM, Isackson C, Wunder R, Fletcher TH, Butler BW, Weiase DR (2010). Experimental measurements during combustion of moist individual foliage samples. International Journal of Wildland Fire 19: 153-162. - doi: 10.1071/WFo7 121

Raffa KF, Smalley EB (1995). Interaction of preattack and induced monoterpenoid concentrations in host conifer defense against bark beetle-fungal complexes. Oecologia 102: 285-295. doi: 10.1007/BF00329795

Raffalli N, Picard C, Giroud F (2002). Safety and awareness of people involved in forest fires suppression. In: Proceedings of IV International Conference on Forest Fire Research 2002 Wildland Fire Safety Summit "Forest Fire Research and Wildland Fire Safety" (Viegas DX ed). Luso (Coimbra, Portugal) 18-23 Nov 2002. Millpress Science Publishers, Rotterdam, Netherlands, pp. 1. [online] URL: http://www.millpress.nl/ shop/abooks/ICFFR4/pdf/167.pdf

Rothermel RC (1972). A mathematical model for predicting fire spread in wildland fuels. Research Paper INT-115, USDA Forest Service, Ogden, UT, USA, pp. 40. [online] URL: http:// www.snap.uaf.edu/webshared/AKFireModelin gWorkshop/Rothermel1972INT-115.pdf

Santana VM, Marrs RH (2014). Flammability properties of British heathland and moorland vegetation: models for predicting fire ignition. Journal of Environmental Management 139: 8896. - doi: 10.1016/j.jenvman.2014.02.027

Steele CL, Katoh S, Bohlmann J, Croteau R (1998). Regulation of oleoresinosis in grand fir (Abies grandis). Plant Physiology 116: 1497-1504. - doi: 10.1104/pp.116.4.1497

Valette JC (2007). EUFIRELAB Euro-Mediterranean Wildland Fire Laboratory, a wall-less laboratory for wildland fire sciences and technologies in the Euro-Mediterranean region. In: Proceedings of the " 4 th Wildfire International Conference". Seville (Spain) 13-17 May 2007. Organismo Autónomo de Parques Nacionales, Madrid, Spain, pp. 18, ST4.

Van Wagner CE (1977). Conditions for the start and spread of crown fire. Canadian Journal of Forest Research 7: 23-34. - doi: 10.1139/x77-004 Varner JM, Kane JM, Kreye JK, Engber E (2015).
The flammability of forest and woodland litter: a synthesis. Current Forestry Reports 1: 91-99. doi: 10.1007/s40725-015-0012-X

Viegas DX, Simeoni A (2010). Eruptive behaviour of forest fires. Fire Technology 47: 303-320. doi: 10.1007/s10694-010-0193-6

Weise DR, White RH, Beall FC, Etlinger M (2005). Use of the cone calorimeter to detect seasonal differences in selected combustion characteristics of ornamental vegetation. International Journal of Wildland Fire 14: 321-338. - doi: 10.107 1/WF04035

Weise DR, Koo E, Zhou X, Mahalingam S, Morandini F, Balbi JH (2016). Fire spread in chaparral a comparison of laboratory data and model predictions in burning live fuels. International Journal of Wildland Fire 25: 980-994. - doi: 10.10 71/WF15177

White CS (1994). Monoterpenes: their effect on ecosystem nutrient cycling. Journal of chemical ecology 20: 1381-1406. - doi: 10.1007/BF02059 813

White RH, Zipperer WC (2010). Testing and classification of individual plants for fire behaviour: plant selection for the wildland-urban interface. International Journal of Wildland Fire 19: 213-227. - doi: 10.1071/WF07128

Wold H (1985). Partial least squares. In: "Encyclopaedia of Statistical Sciences, vol. 6" (Kotz S, Johnson NL eds). John Wiley and Sons, New York, USA, pp. 581-591. - [online] URL: http:// onlinelibrary.wiley.com/doi/10.1002/0471667196 .ess1914.pub2/abstract

\section{Supplementary Material}

Tab. S1 - Original data of fuel moisture content (FMC) and ignition probability (IP) used for the calculation of the logistic model.

\section{Link: Danti_2327@supplo01.pdf}

